\title{
Rheumatoid heart disease with complete heart block
}

\author{
M. HARRIS1 \\ From the Department of Pathology, University of Bristol
}

SYNOPSIS A case of florid rheumatoid heart disease with complete heart block is described, and the histopathology of the atrioventricular conducting tissue is described in detail.

Although the association of heart block with rheumatoid arthritis has been noted by a number of authors (Cathcart and Spodick, 1962; Lebowitz, 1963), examples where a detailed pathological study of the heart has been recorded are extremely rare and it is for this reason that the following patient is described.

\section{Case Report}

The patient was a woman aged 69 years who had suffered from severe rheumatoid arthritis for seven years. The joints affected were the shoulders, wrists, fingers, neck, and knees. In June 1967 she was admitted to hospital for treatment of a urinary infection; her blood pressure was 160/80 $\mathrm{mm} \mathrm{Hg}$, the pulse rate was 76 beats per minute, and no abnormality of the heart was found on clinical examination.

In August 1967 a course of treatment with ACTH, 40 units per day, was started but was stopped after five days because the patient developed tachycardia and oedema of the legs.

On 11 September 1967 she was admitted to hospital in congestive heart failure. A loud systolic murmur was heard in the aortic area. The pulse rate was 40 beats per minute and complete heart block was diagnosed. On 13 September she had repeated episodes of cardiac standstill and unconsciousness; an intravenous pacemaker was inserted and the heart was paced at 70 beats per minute, but, although there was slight improvement she remained confused and in heart failure, and died on 14 September.

On the day of her death the plasma electrolytes were: urea $104 \mathrm{mg} \%$, sodium 140 m-equiv/1, potassium more than $8 \mathrm{~m}$-equiv/1, chloride 104 m-equiv/1, and bicarbonate $12 \mathrm{~m}$-equiv/1. The cause of the marked hyperkalaemia is unknown.

\section{Necropsy Findings}

There was moderate oedema of both ankles.

The joints of both hands showed typical rheumatoid deformities, but other joints appeared normal externally.

The heart weighed $345 \mathrm{~g}$ and there was dilatation of all its chambers, notably of the left ventricle which was slightly hypertrophied. The tip of the cardiac pacemaker was in perfect position in the right ventricle. The aortic valve bore a rounded thrombotic vegetation $(0.6 \mathrm{~cm}$ diameter) on the superior aspect of the left coronary cusp, the cusp itself being slightly thickened. There was no significant growth from a culture of a fragment of the vegetation. Only the basal third of the right coronary cusp was present and was strikingly thickened; the remainder of the cusp had been destroyed. The non-coronary cusp appeared normal. Apart from the presence of a small white nodule $(0.3 \mathrm{~cm}$ diameter) in the base of the anterior cusp, the mitral valve was macroscopically normal. The pulmonary and tricuspid valves were normal. 


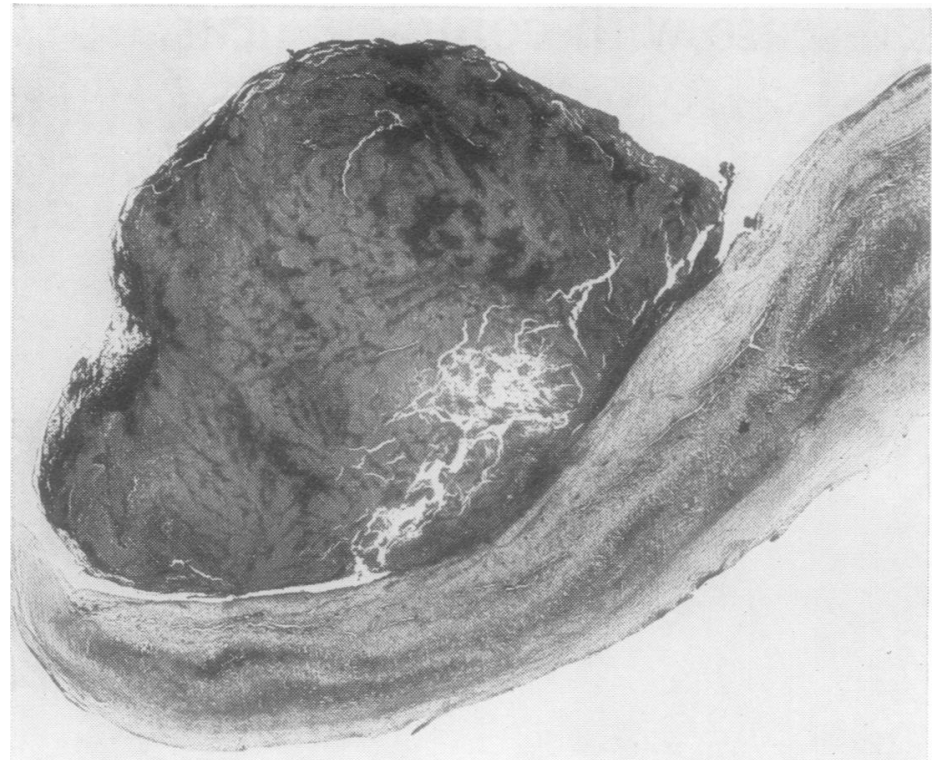

Fig. 1 Left coronary cusp of aortic valve. Strips of necrosis, appearing dark in the picture, are apparent in the cusp beneath the thrombotic vegetation. Haematoxylin and eosin $\times 17$.

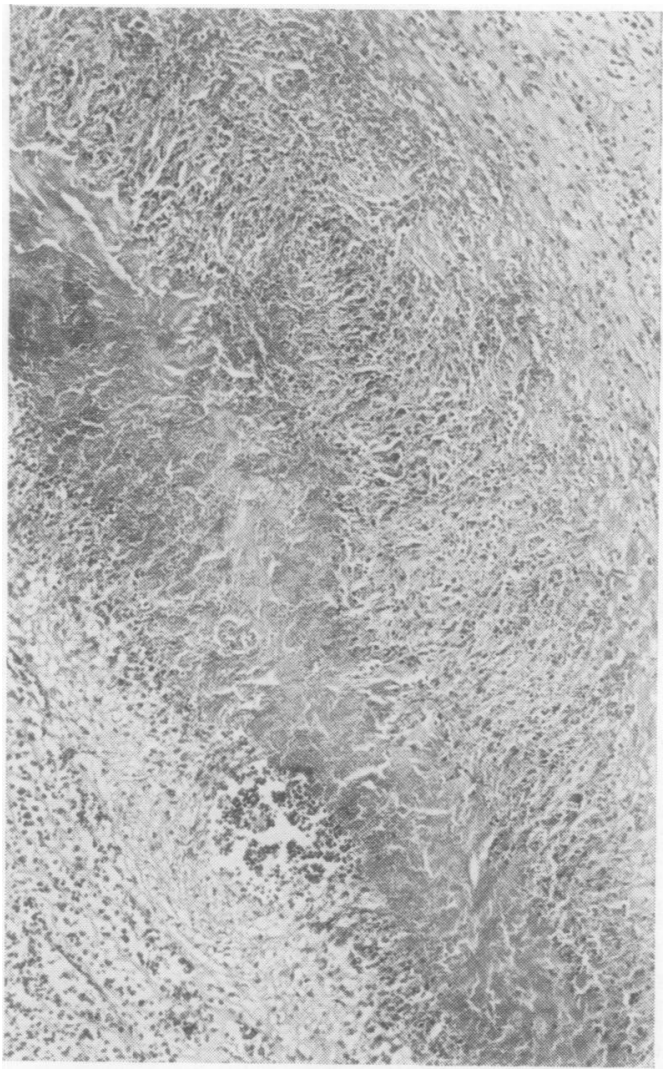

Fig. 2 Higher-power photomicrograph of the left coronary cusp. The typical structure of a rheumatoid granuloma is now apparent wtih a central necrotic zone bordered by a palisade of fibroblasts and histiocytes. Haematoxylin and eosin $\times 105$.
The coronary arteries were almost free from $\frac{\varrho}{5}$ atheroma and no occlusions were found. Theo myocardium appeared normal. There was mil\& aortic atheroma but no evidence of aortitis.

No other abnormality was found.

\section{Histology}

METACARPO-PHALANGEAL JOINT

There is complete destruction of the articular cartilage which is replaced by vascular fibrous tissue infiltrated by chronic inflammatory cells? The synovium shows papillary hyperplasia anơ there is osteoporosis of the adjacent bone.

AORTIC VALVE

The vegetation on the left coronary cusp (Fig. 1 P has the structure of recently formed thrombus $\vec{P}$ there is no organization of its base and no bacteria are seen in a Gram-stained section. Within the cusp, beneath the vegetation, there is a strip o® fibrinoid necrosis bordered by fibroblasts anto histiocytes arranged in palisade fashion, appearances typical of a rheumatoid granuloma (Figs 1 and 2). Around the granuloma there is fibrosiso and infiltration by numerous lymphocytes and plasma cells. Similar changes, including granu음 lomata, are present in the valve ring and although chronic inflammatory cell infiltration extends into the adventitia at the root of the aorta there is $\vec{B}$ no inflammation or fibrosis of the aortic media?

The remnant of the right coronary cusp show severe fibrosis and contains several rheumatoid granulomata.

MITRAL VALVE

The nodule in the base of the anterior cusp is due to the presence of rheumatoid granulomatao with accompanying fibrosis and chronic inflam? matory cell infiltration.

Rheumatoid granulomata are also found in the upper part of the muscular interventricularos septum and in the interatrial septum.

It is of interest at this stage to note an addi tional feature which is present in several of the otherwise typical rheumatoid nodules. This is the presence of polymorph infiltration, sometimest marked, at the periphery of the necrotic zones of the nodules. Often the polymorphs show considerable pyknosis and karyorrhexis and wheres this occurs the necrotic material acquires aब variable degree of basophilia. Within such $\frac{P}{D}$ basophilic zones it is still possible to detect? fibrinoid material and there is no doubt that the basophilic zones constitute part of theo rheumatoid nodules since they can be seen to be continuous with the typical, brightly eosinot philic, necrotic areas elsewhere in the granulomata. 
The atrioventricular conducting tissue was examined by the technique of Hudson (1963). In all sections from proximal to distal ends of the system the conducting tissue is abnormal. The mildest changes, seen in the most proximal parts of the system, are diffuse infiltration by lymphocytes, plasma cells, and histiocytes, with slight interstitial fibrosis and some vacuolation of the muscle fibres. The inflammatory cell infiltration in this and all other regions involves adjacent adipose tissue, fibrous tissue, and atrial muscle and is continuous with the inflammatory changes at the base of the aortic valve.

In addition to the above features, which are not specific, there are zones of necrosis in all regions of the system. In any one section up to half of the conducting tissue may be necrotic. For the most part the necrotic zones are basophilic and infiltrated by many polymorphs but in a few small areas the basophilia is seen to merge with zones of fibrinoid necrosis bordered by histiocytes, fibroblasts, and a few multinucleated giant cells forming an indistinct palisade pattern (Fig. 3). It is considered, because of these features, and by analogy with the essentially similar findings in the valvular lesions, that the necrotic lesions in the conducting tissue are rheumatoid granulomata.

There is no arteritis of the vessels within the conducting tissue nor in any other tissues and neither is there any vascular thrombosis.

No other histological abnormality is found.

\section{Discussion}

The histological lesions of rheumatoid heart disease may be specific or non-specific. The specific lesions are granulomata identical in appearance to subcutaneous rheumatoid nodules (Cruickshank, 1958) and may occur in the pericardium, myocardium, or endocardium. The valvular lesions in the case reported here are undoubtedly of the specific granulomatous variety and, together with the long history of rheumatoid arthritis, firmly establish the diagnosis of rheumatoid disease of the heart with unusually severe damage to the aortic valve.

For reasons given in the histological report the necrotic lesions in the atrioventricular conducting tissue are also considered to be rheumatoid granulomata.

Clinical studies show that rheumatoid disease of the heart may present in a variety of ways, including heart block. Cathcart and Spodick (1962) studied 254 patients with rheumatoid arthritis and found 88 with evidence of organic heart disease. Of these, 29 were classified as 'indeterminate heart disease' on the basis of unusual cardiac findings and were probably examples of rheumatoid disease of the heart; nine of them had some form of heart block.

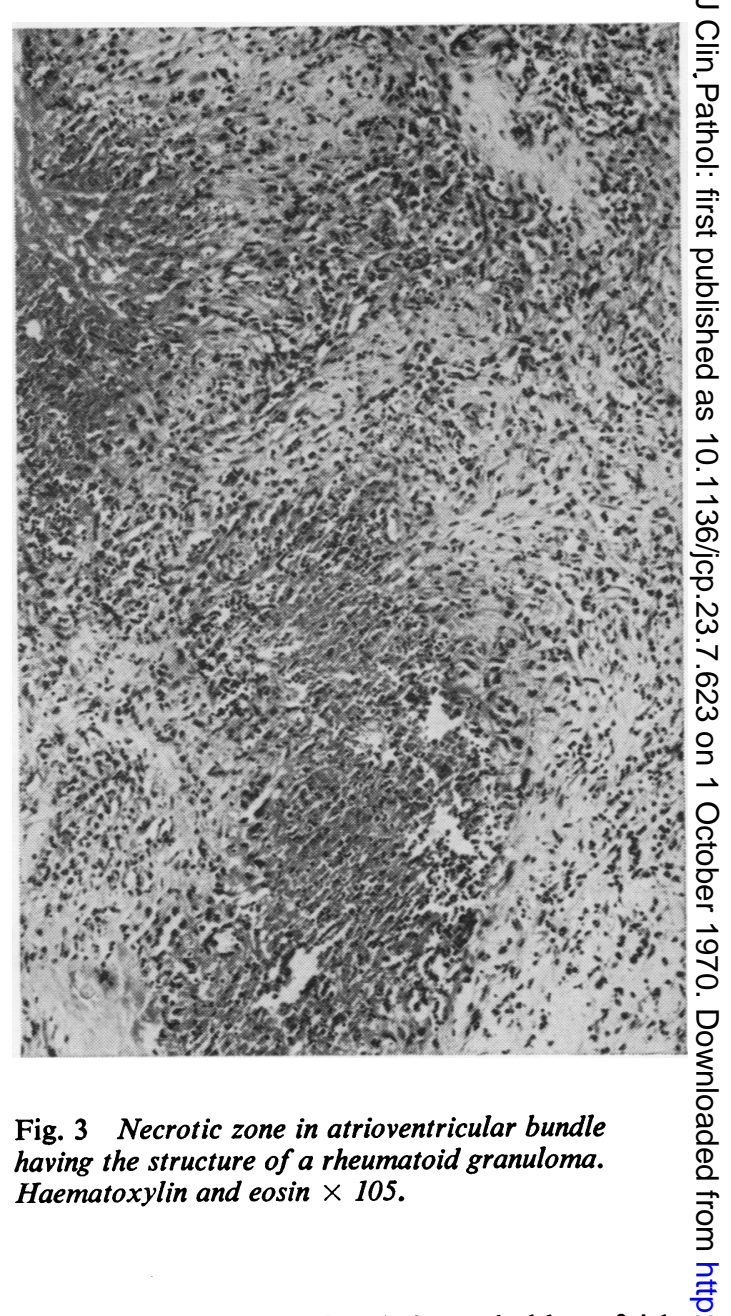

Thus, although heart block is probably a fairly frequent manifestation of rheumatoid heart $\overline{0}$ disease, it is, in absolute figures, an uncommon $\frac{-}{3}$ complication of rheumatoid arthritis. Not surprisingly, there are very few cases on record $ᄋ$ where a full histopathological study of the heart has been made and even fewer in which the 은 atrioventricular conducting tissue has been $D$ examined. Those found in the literature are summarized in the Table.

Nine cases of heart block, two of which were of complete, from a paper by Lebowitz (1963) have $N$ been excluded from the Table because the patho- N logical details recorded are scanty.

Examples of heart block associated with ankylosing spondylitis have also been excluded from $\mathbb{\Phi}$ the Table because it is felt that it is more helpful ? to regard this condition as being distinct from $\frac{T}{T}$ rheumatoid arthritis, although related to it. Nevertheless, it is of interest that there appears $\stackrel{\mathbb{P}}{\mathbb{P}}$ to be a definite association between ankylosing $\underset{\mathbb{D}}{\mathbb{D}}$ spondylitis and heart block, the latter being found in $8.5 \%$ of 519 patients with spondylitis by Graham and Smythe (1958). In all but four응 of these patients with heart block, none of whom were necropsied, there was also aortic incompe- $\frac{\overline{0}}{\bar{y}}$ 


\begin{tabular}{|c|c|c|c|c|c|c|c|}
\hline Reference & Age & $\operatorname{Sex}$ & $\begin{array}{l}\text { Duration } \\
\text { of Arthritis }\end{array}$ & $\begin{array}{l}\text { Subcutaneous } \\
\text { Nodules }\end{array}$ & $\begin{array}{l}\text { Type of } \\
\text { Heart Block }\end{array}$ & Pathology of Heart & $\begin{array}{l}\text { Pathology of Atrio- } \\
\text { ventricular System }\end{array}$ \\
\hline $\begin{array}{l}\text { Handforth \& } \\
\text { Woodbury } \\
\text { (1959) } \\
\text { Case } 2 \\
\text { Gowans } \\
\text { (1960) }\end{array}$ & 59 & $\mathbf{M}$ & 49 years & $\rightarrow$ & Complete & $\begin{array}{l}\text { Rheumatoid nodule at } \\
\text { upper end of inter- } \\
\text { ventricular septum; } \\
\text { valves not diseased } \\
\text { Rheumatoid nodules in } \\
\text { epicardium, endocardium, } \\
\text { right atrial appendage, and } \\
\text { interventricular septum; } \\
\text { valves not diseased }\end{array}$ & Not recorded \\
\hline $\begin{array}{l}\text { Carpenter } \\
\text { et al } \\
(1967)\end{array}$ & 65 & $\mathrm{~F}$ & 15 years & $\div$ & $\begin{array}{l}\text { LBBB }^{1} \\
\text { and } \\
\text { first degree }\end{array}$ & $\begin{array}{l}\text { Acute and healed } \\
\text { pericarditis; rheumatoid } \\
\text { nodules in all valves, } \\
\text { epicardium, and } \\
\text { myocardium }\end{array}$ & $\begin{array}{l}\text { Proximal portion of left } \\
\text { bundle branch completely } \\
\text { interrupted by a } \\
\text { rheumatoid granuloma }\end{array}$ \\
\hline $\begin{array}{l}\text { Kirk \& Cosh } \\
\text { (1969) } \\
\text { Case } 10\end{array}$ & 69 & $F$ & 7 years & $\div$ & $\begin{array}{l}\text { First } \\
\text { degree }\end{array}$ & $\begin{array}{l}\text { Pericardial adhesions; } \\
\text { rheumatoid nodules in } \\
\text { epicardium, between roots } \\
\text { of both great vessels; } \\
\text { fibrinoid change in some } \\
\text { intramural arteries }\end{array}$ & $\begin{array}{l}\text { Rheumatoid granulomata } \\
\text { in atrioventricular node an } \\
\text { bundle of His }\end{array}$ \\
\hline This case & 69 & $\mathbf{F}$ & 7 years & $?$ & Complete & $\begin{array}{l}\text { Rheumatoid granulomata } \\
\text { of aortic and mitral } \\
\text { valves; aortic vegetation; } \\
\text { destruction of one aortic } \\
\text { cusp }\end{array}$ & $\begin{array}{l}\text { Rheumatoid } \\
\text { granulomata in all parts } \\
\text { of atrioventricular system }\end{array}$ \\
\hline
\end{tabular}

Table Summary of reported cases

${ }^{1}$ LBBB $=$ left bundle branch block.

tence suggesting that there is usually an accompanying aortitis. This correlates with the cases of spondylitis recorded by Weed, Kulander, Mazzarella, and Decker (1966) and by Sobin and Hagstrom (1962) in which there was nonspecific chronic inflammatory destruction of the atrioventricular conducting tissue in continuity with aortic inflammation. It seems possible that the proximity of the aortic valve to the atrioventricular conducting tissue, combined with the susceptibility of the aortic valve to inflammation in ankylosing spondylitis (Clark, Kulka, and Bauer, 1957), determines the apparent risk of heart block in this disease, rather than there being a specific susceptibility of the conducting tissue to the disease process. A similar argument cannot, however, be applied to heart block in rheumatoid arthritis because, although in the case recorded here there was aortic valve damage in continuity with the lesions of the conducting tissue, there was no aortic valve disease in three of the other four cases summarized in the Table.

I should like to thank Dr D. W. Barritt for permission to publish the clinical details and Dr J. A. Cosh for giving me details of case 10 from his publication.

Thanks are also due to $\mathrm{Mr} \mathrm{C}$. Jeal for the photomicrographs and to Mrs A. Daniel and Mrs V. Horler for the typing.
References

Carpenter, D. F., Golden, A., and Roberts, W. C. (1967). Quad rivalvular rheumatoid heart disease associated with left bundle branch block. Amer. J. Med., 43, 922-929.

Cathcart, E. S., and Spodick, D. H. (1962). Rheumatoid hear? disease; a study of the incidence and nature of cardias lesions in rheumatoid arthritis. New Engl. J. Med., 266 959-964.

Clark, W. S., Kulka, J. P., and Bauer, W. (1957). Rheumatoip̧ aortitis with aortic regurgitation: an unusual manifesta@ tion of rheumatoid arthritis (including spondylitis). Amer J. Med., 22, 580-592.

Cruickshank, B. (1958). Heart lesions in rheumatoid disease. $J 3$ Path. Bact. 76, 223-240.

Gowans, J. D. C. (1960). Complete heart block with Stokes Adams syndrome due to rheumatoid heart disease: report. of a case with autopsy findings. New Engl. J. Med., 262 1012-1014.

Graham, D. C., and Smythe, H. A. (1958). The carditis and aortitis of ankylosing spondylitis. Bull. rheum. Dis., 9글 171-174.

Handforth, C. P., and Woodbury, J. F. L. (1959). Cardiovasculaô manifestations of rheumatoid arthritis. Canad. med. Ass J., 80, 86-90.

Hudson, R. E. B. (1963). The human conducting system and it examination. J. clin. Path., 16, 492-498.

Kirk, J., and Cosh, J. (1969). The pericarditis of rheumatoif arthritis. Quart. J. Med., 38, 397-423.

Lebowitz, W. B. (1963). The heart in rheumatoid arthriti (rheumatoid disease). Ann. intern. Med., 58, 102-123.

Sobin, L. H., and Hagstrom, J W. C. (1962). Lesions of cardiać conduction tissue in rheumatoid aortitis. J. Amer. med Ass., 180, 1-5.

Weed, C. L., Kulander, B. G., Mazzarella, J. A., and Decker, J. L. (1966). Heart block in ankylosing spondylitis. Arch intern. Med., 117, 800-806. 